\title{
Risk Factor Frequency for Learning Disabilities in Low Socioeconomic Level Preschool Children in Mexico City
}

\author{
Elizabeth Zambrano-Sánchez ${ }^{1}$ \\ María del Consuelo Martínez-Wbaldo² \\ Adrián Poblano ${ }^{3}$
}

The objective was to identify the frequency of risk factors for Learning Disabilities (LD) in low socioeconomic level children in Mexico City. We studied children by means of: Wechsler, Bender-Gestalt, and Human drawing tests. Average age of male subjects was 5.6 0.9 years, while that of the female group was $5.4 \pm 0.5$ years. In male subjects, average Total intelligence quotient (T-IQ) score was $98 \pm 12.2$ while, in the female group, this was $99 \pm 12.2$. On the Bender-Gestalt test, male subjects had a mental and visual-motor average age of $<1$ year under chronological age. Female subjects had a mental and visual-motor age 8-7 months under the norm. On the Human drawing test, in male and female subjects, the most frequent at-risk features comprised: self-isolation in $25 \%$ of subjects, shyness in $22.4 \%$, and poor internal controls in $22 \%$. In conclusion, we found a high at-risk factor frequency for LD in children of low socioeconomic strata. We highlight the importance of screening children before they attain school age.

Descriptors: Learning Disorders; Child, Preschool; Intelligence; Human Development; Risk Factors.

\footnotetext{
${ }^{1}$ BSc, Department of Epidemiology, National Institute of Rehabilitation (NIR), Mexico City OJO, Mexico. E-mail: drthinner@starmedia.com.

2 M.Sc., Department of Epidemiology, National Institute of Rehabilitation (NIR), Mexico City OJO, Mexico. E-mail: jperezmorenoh@yahoo.com.mx.

${ }^{3}$ DSc, Laboratory of Cognitive Neurophysiology, National Institute of Rehabilitation (NIR), Mexico City OJO, Mexico. School of Nurses, National University of Mexico, Mexico City, Mexico. Email: drdyslexia@latinmail.com.
}

Corresponding Author:

Adrián Poblano

Calzada México-Xochimilco 289

Col. Arenal Guadalupe.

Deleg. Tlalpan, cp 14389. Mexico City, Mexico

E-mail: drdyslexia@latinmail.com 


\title{
Frequência de fatores de risco para dificuldade de aprendizagem em pré-escolares com baixo nível socioeconômico, na Cidade do México
}

Este estudo objetivou identificar a frequência de fatores de risco para dificuldade de aprendizagem (DA) em crianças com baixo nível socioeconômico, na Cidade do México. A escala de inteligência Wechsler, desenho da figura humana e o teste gestáltico visomotor

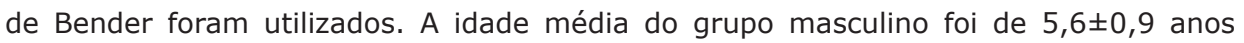
e do grupo feminino 5,4 $\pm 0,5$ anos. O quociente intelectual total (QI-T) foi de $98 \pm 12$ no grupo masculino e $99 \pm 12,2$ no grupo feminino. No teste de Bender, os meninos apresentaram idade mental e visomotora um ano abaixo da idade cronológica, enquanto que as meninas apresentaram idade mental e visomotora 7-8 meses abaixo do normal. As características de alto risco que apresentaram maior frequência, tanto nos meninos como nas meninas, no teste do desenho de figura humana, foram: autoisolamento $25 \%$, timidez 22,4 e controle interno deficiente $22 \%$. Concluindo, alta frequência de fatores de risco para DA foi encontrada em crianças de baixo nível socioeconômico. É importante destacar a importância de se identificar pré-escolares em risco de DA.

Descritores: Transtornos de Aprendizagem; Pré-escolar; Inteligência; Desenvolvimento Humano; Fatores de Risco.

\section{Frecuencia de factores de riesgo para problemas de aprendizaje en preescolares de bajo nivel socioeconómico en la Ciudad de México}

\begin{abstract}
Nuestro objetivo fue identificar la frecuencia de factores de riesgo para problemas de aprendizaje (PA) en niños de bajo nivel socioeconómico de la Ciudad de México. Se utilizaron las pruebas de inteligencia de Wechsler, Gestáltica Visuomotora de Bender y del Dibujo de la figura humana. La edad promedio en el grupo masculino fue $5,6 \pm 0,9$ años, del femenino fue $5,4 \pm 0,5$. En los hombres, el cociente intelectual total (CI-T) fue $98 \pm 12,2$, en mujeres fue $99 \pm 12,2$. En la prueba de Bender, los hombres mostraron una edad mental y visuomotora un año menor que la cronológica, las mujeres tuvieron una edad mental y visuomotora 7-8 meses por debajo de la norma. En la Prueba de la figura humana, los hombres y mujeres mostraron mayor frecuencia de: auto-aislamiento $25 \%$, timidez $22,4 \%$ y controles internos pobres $22 \%$. En conclusión encontramos una alta frecuencia de factores de riesgo en preescolares de bajo nivel socioeconómico, destacamos la importancia de identificar a los preescolares propensos a tener problemas de aprendizaje (PA).
\end{abstract}

Descriptores: Trastornos del Aprendizaje; Preescolar; Inteligencia; Desarrollo Humano; Factores de Riesgo.

\section{Introduction}

The age between 4 and 6 years is a critical period for emotional and cognitive development in children ${ }^{(1)}$. The families of these children push them to establish more social contacts with their peers. In Mexico, it is mandatory for children at these ages to attend preschool education.

Many papers highlight the importance of early detection of risk factors for Learning disabilities (LD), such as emotional and cognitive alterations during this period in the life of the child. One useful strategy is to screen neuropsychological performance in order to identify the children's abilities and reinforce their weaknesses so as to ensure better academic performance ${ }^{(2-3)}$.

Different investigations emphasize the importance of language acquisition as one of the main factors for reading performance $^{(4)}$. It is a frequent clinical observation to 
identify children with reading disability with antecedents of language delay during their development. On the other hand, children with a language disorder frequently develop a reading alteration later, when they reach school age ${ }^{(5-6)}$. In a previous paper, we identified the main risk factors for LD in an outpatient population seeking consultation at the National Institute of Communication Disorders in Mexico City, in which we observed that malnutrition, antecedents of language disorder, perinatal risk factors and presence of neurologic soft signs were the main variables associated with reading disability ${ }^{(6)}$.

Early detection of children with LD enables health professionals, including nurses, to identify and refer these groups of at-risk children to intervention programs. To accomplish this objective, we are able to utilize standardized psychometric examinations, such as the Wechsler intelligence scale for pre-school and school children (WIPPSI), the Bender visual-motor Gestalt test, and the Human figure drawing examination.

At present, there are few studies on early detection of LD in preschool children in Mexico. LD prevalence in Mexican children is unknown(7). Lower socioeconomic groups may have a higher prevalence of mental alterations and their risk factors may be more frequently observed than in higher socioeconomic groups. Thus, early detection of LD emerges as a rational strategy for rapid attention to academic problems in lower socioeconomic level groups.

This research aimed to identify the frequency of emotional risk factors for LD in a representative sample of children from the lower socioeconomic strata at Infant Developmental Centers in Mexico City. In addition, we studied emotional and cognitive features examined by means of WPPSI, Bender visual-motor Gestalt and Human drawing tests.

\section{Materials and Methods}

\section{Subjects}

We designed a cross-sectional study to detect frequency of risk factors for LD in a sample of preschool children in Mexico City. Children were selected from populations attending eight Centers of Development for Infants (CENDI) funded by the Federal District Government; the children were representative of the low socioeconomic strata. One hundred sixty-two children were selected at random from a generated list, using statistical software. Inclusion criteria were as follows: subjects of both genders; ages between 4 and 6 years; regular attendance of a CENDI, and with adequate hearing and collaborative behavior. Exclusion criteria comprised: external congenital malformations, genetic diseases, severe chronic diseases, cerebral palsy, deafness, blindness and epilepsy. Parents and children were informed about the purposes and benefits of the research and the importance of their child's participation. Informed and signed consent was required according to the Institute's Research Committee and the Helsinki Declaration $^{(8)}$. Approval of the protocol was obtained from the Institute's Research Committee.

\section{Procedures}

We performed individual examinations and tested three subjects per day at CENDI installations in a separate noise-isolated room. We employed three psychometric tests: 1 . Wechsler intelligence scale reviewed for preschool children (WPPSI); 2. Bender visual-motor Gestalt test, and 3. Human figure drawing test. Examination of each subject was performed during two two-hour sessions. In the first session, Human figure drawing and Bender visual-motor Gestalt tests were applied, while the WPPSI was conducted during a second appointment.

The WPPSI-Spanish version consists of a test of two sub-scales that can be combined to determine a total Intelligence Quotient (IQ) score that measures general intelligence performance. The two sub-scales include the following: verbal, and performance intelligence sections. The verbal intelligence quotient (V-IQ) scale was divided into: information management, vocabulary, arithmetic, resemblances and comprehension. The performance intelligence quotient (P-IQ) scale was divided into: animal house, incomplete figures, labyrinths, geometric designs and prism designs. Each sub-scale was considered independent and data from each sub-scale was compared with data from the reference table for each V-IQ, for each P-IQ score calculation, and for total IQ score calculation. Total IQ scores were classified in the following seven levels: $\geq 130$, very superior; 120-129, superior; 110-119, normal-brilliant; 90-109, normal; 80-89, normal-awkward; 70-79, borderline; and $\leq 69$, mental retardation.

The Bender visual-motor Gestalt test permitted us to examine visual-motor performance in order to detect dysfunction in both areas. This test was used because there is a close relationship between visual-motor performance and other functions, such as spatial memory, visual perception, motor coordination and the need to learn to read. Visual-motor performance results from integrative brain activity with regard to the input-output of the brain cortex's occipital-parietal and frontal regions. 
The Human figure drawing test was employed to measure mental maturation and certain personality features. In this test, the structure and design of the children's drawing are determined by age and maturation level. When a drawing's features were examined, we weighed the value of association of functions, analytic observation, discrimination, memory for details, spatial reasoning, judgment, abstraction and visual-motor coordination. This test was also employed to ascertain emotional personality features.

\section{Data analysis}

Total child population of the eight CENDIs was 933 subjects; we chose 162 children of both genders at random, as previously described. Sample size was calculated with $95 \%$ statistical power to observe the independent variable, with $5 \%$ of error, by means of the $\mathrm{STAT}^{\circledR}$ software program. We measured mean and standard deviation (SD) of continuous variables and percentages in binomial variables. Continuous variable differences were compared by Student's $t$ test, and differences in binomial variables were compared by the $X^{2}$ test. Afterwards, we calculated correlation coefficients among psychometric data by means of Spearman's method. The a-priori accepted alpha was $\leq 0.05^{(9)}$.

\section{Results}

Average age was $5.9 \pm 0.5$ years. Gender distribution of the sample was as follows: $54 \%$ males and $46 \%$ females. Average age of male subjects was $5.6 \pm 0.9$ years, and average age in the female group was $5.4 \pm 0.5$ years. Age distribution was as follows: $30.7 \%$ were 4 years; $32.6 \%$ were 5 years, and $36.3 \%$ were 6 years of age. Distribution by CENDI and age are shown in Table 1.

Table 1 - Sample distribution by school, grade and gender

\begin{tabular}{|c|c|c|c|c|c|c|c|c|}
\hline \multirow{2}{*}{$\begin{array}{c}\text { CENDI } \\
n\end{array}$} & \multirow{2}{*}{$\begin{array}{c}\text { Population } \\
n\end{array}$} & \multirow{2}{*}{$\begin{array}{c}\text { Sample } \\
n\end{array}$} & \multirow{2}{*}{$\begin{array}{c}2^{\text {nd }} \text { grade } \\
n\end{array}$} & \multirow{2}{*}{$\begin{array}{c}3^{\text {rd }} \text { grade } \\
n\end{array}$} & \multicolumn{2}{|c|}{$2^{\text {nd }}$ grade by gender } & \multicolumn{2}{|c|}{$3^{\text {rd }}$ grade by gender } \\
\hline & & & & & $\begin{array}{c}\text { Males } \\
n\end{array}$ & $\begin{array}{c}\text { Females } \\
n\end{array}$ & $\begin{array}{c}\text { Males } \\
n\end{array}$ & $\begin{array}{c}\text { Females } \\
n\end{array}$ \\
\hline 1 & 86 & 17 & 8 & 9 & 4 & 4 & 4 & 5 \\
\hline 2 & 104 & 17 & 10 & 8 & 4 & 6 & 4 & 4 \\
\hline 3 & 99 & 15 & 7 & 8 & 4 & 3 & 4 & 4 \\
\hline 4 & 112 & 29 & 18 & 12 & 10 & 8 & 6 & 6 \\
\hline 5 & 787 & 9 & 4 & 5 & 2 & 2 & 1 & 4 \\
\hline 6 & 123 & 21 & 10 & 11 & 6 & 4 & 8 & 3 \\
\hline 7 & 148 & 28 & 13 & 13 & 7 & 6 & 8 & 5 \\
\hline 8 & 181 & 26 & 14 & 12 & 8 & 6 & 7 & 5 \\
\hline Total & 931 & 162 & 84 & 78 & 46 & 39 & 42 & 36 \\
\hline
\end{tabular}

Federal District (Mexico City)-run Infant Development Center (CENDI). Columns 4-9 indicate the preschool grade in which children were studied

\section{WPPSI}

In both genders, we observed a major percentage of normal results $(56 \%$ in males and $60 \%$ in females, respectively). In the normal-brilliant group, $18.7 \%$ subjects were male and $10 \%$ female while, in the normal-awkward group, $14.06 \%$ were male and $20 \%$ female.

Average total IQ score in the entire sample was $99 \pm 12.9$, average P-IQ score was $99 \pm 14.9$, and average V-IQ score $93 \pm 11.7$, all of which correspond to normal average intelligence. In the group of male subjects, average total IQ score was $98 \pm 12.2$, average P-IQ score was 94 \pm 12.4 , and average V-IQ score was 99 \pm 15.7 , corresponding to normal intelligence. In the group of female subjects, average total IQ score was 99 \pm 12.2 , average P-IQ score was $106 \pm 14.6$, and average V-IQ score was $101 \pm 15.7$, also corresponding to normal intelligence (see Table 2).
Table 2 - Distribution of Intelligence quotient (IQ) and gender

\begin{tabular}{llcc}
\hline \multicolumn{1}{c}{ IQ score } & \multicolumn{1}{c}{ Classification } & \% males & \% females \\
\hline$\geq 130$ & Very superior & 0 & 0 \\
$120-129$ & Superior & 4.6 & 2.5 \\
$110-119$ & Normal-brilliant & 18.7 & 10 \\
$90-109$ & Normal & 56.2 & 60 \\
$80-89$ & Normal-awkward & 14.06 & 20 \\
$70-79$ & Borderline & 4.6 & 5 \\
$\leq 78$ & Mental retardation & 1.5 & 2.5 \\
\hline
\end{tabular}

IQ = Intelligence quotient range ; \% = percentage

\section{Bender Visual-motor Gestalt Test}

Average mental age for both genders was $5.0 \pm 0.5$ years, 9 months under the chronological age norm. Average visual-motor age was $4.8 \pm 0.5$ years, 11 months under that expected by chronological age. Gender 
analyses showed that male subjects had a mental age average of $4.9 \pm 0.5$ years, 1 year under chronologic age, and that average visual-motor age was $4.6 \pm 0.5$ years, 1 year and 3 months less than that expected by chronological age. Female subjects had a mental age average of $5.1 \pm 0.5$ years, 8 months under that expected by the norm, and the female subjects' visual-motor age average was $5.2 \pm 0.4$ years, 7 months under the norm (see Table 3).

Table 3 - Results of the Bender-Gestalt test across the sample

\begin{tabular}{ccc}
\hline Age type (years) & $\boldsymbol{X}$ & SD \\
\hline Chronological & 5.9 & 0.6 \\
Mental & 5.0 & 0.5 \\
Visual-motor & 4.8 & 0.5
\end{tabular}

$X=$ average; $\mathrm{SD}=$ Standard deviation

\section{Human Figure Drawing Test}

The features most frequently associated with risk factors for LD in male subjects were the following: selfisolation, $25 \%$; shyness, $22.4 \%$; poor internal control, $22 \%$; feelings of non-adaptation, $17.6 \%$; poor selfconcept, $16.5 \%$; insecurity, $15.3 \%$, and impulsivity, $14.1 \%$.

In female subjects, the most frequent LD-associated risk factors comprised: self-isolation in 36\%; shyness in $29.8 \%$; poor internal control in $27.2 \%$; insecurity in $18.5 \%$; feelings of non-adaptation in $14.2 \%$, and impulsivity in $12.9 \%$ (see Figure 1 ).

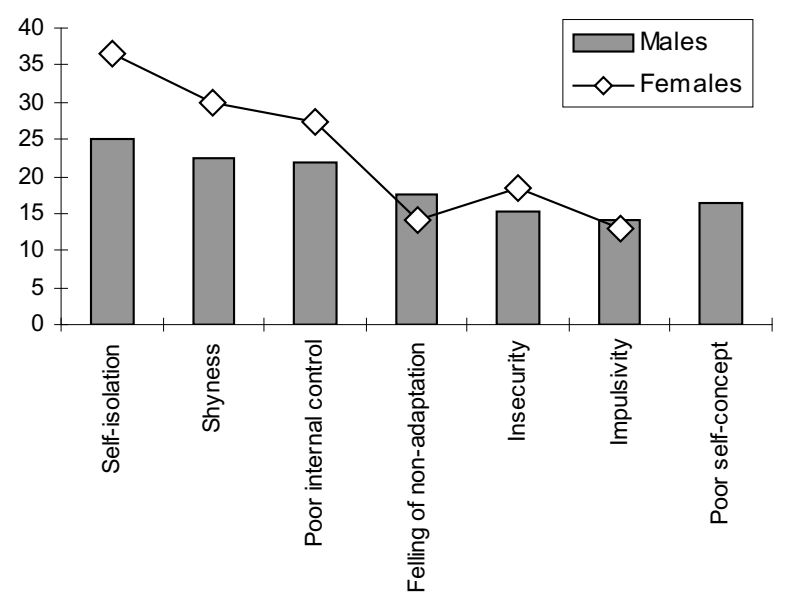

Figure 1 - Frequency of emotional risk factors in asymptomatic and healthy preschool children in the sample

\section{Significant correlations}

We found significant correlations in male subjects between total IQ and V-IQ $(0.65, p=0.05)$ and with P-IQ $(0.65, p=0.05)$. In female subjects, we found a significant correlation between total IQ and V-IQ $(0.77, p=0.04)$. In the entire sample (male and female subjects), we found a significant correlation between mental age and visual-motor age on the Bender visual-motor Gestalt test $(0.89, p=0.02)$.

\section{Discussion}

Through this investigation, we found that a significant percentage of asymptomatic and intelligent preschool-aged children from low socioeconomic strata are at risk for $L D$. The more frequent risk factors detected in this study were the following: visual-motor immaturity, shyness and poor internal controls. These data support the idea that a large percentage of preschool children in Mexico City (12-36\%) have cognitive and emotional sub-clinical alterations, which can disturb their academic performance later ${ }^{(10)}$. The majority of these children are not detected previously as having these troubles; thus, they do not receive treatment and special care at school or in extra-curricular sessions; the at-risk condition is worse in children from a poor and non-stimulating socioeconomic stratum(11-12).

There are several investigations that emphasize the role of intelligence in the acquisition of complex cognitive abilities like reading and writing(13-14). Resolution of complex problems requires learning to read and write, which demand a high degree of intellectual work. Therefore, IQ score results falling within adequate ranges promote good academic learning. Fortunately, we did not observe a high frequency of low IQ scores; this finding can be explained by the fact that the number of cases studied is low, and that CENDI school principals and teachers preferably recruit children without developmental abnormalities.

Visual perception disorders comprise another chapter of primary importance in LD research. In a classical study performed by the team of Maslow and Frostig in preschool and children in their first year at elementary school, the authors found a significant correlation between visual perception deficits and the presence of learning and behavioral disorders ${ }^{(15)}$. Recently, researchers found that students with emotional disorders in elementary school exhibited increased frequencies of behavioral, learning disabilities and 
cognitive deficits in memory, language, attention, social relationships, and in emotional disorders ${ }^{(16)}$. Our data are in agreement with these, because we found a high frequency of visual-motor alterations, which placed our preschool children at high risk for academic failure.

The frequency of fine motor and motor coordination alterations has been mentioned as a possible cause of specific learning disabilities ${ }^{(17)}$. Many investigators have found that children with reading disorders possess deficits when facing fine motor and bimanual coordination tasks and when these results are compared with those of a control group (18-19), as we observed in our sample.

Recently, certain researchers have cited the role of inter-callosum transference in the visual-spatial information processing of children with dyslexia, which is an interesting hypothesis and deserves additional attention ${ }^{(20)}$. This observation could support our finding that the high frequency of visual-spatial alterations in our preschool children is due to transient trans-callosal dysfunction, and continued follow-up is needed in children to weigh the role of the Corpus callosum in the development of LD in reading and writing.

Mental disorders display an increased frequency in children with LD. In Mexico, authors found a high prevalence of mental disorders (13\%) among children from elementary schools in Mexico City who were tested by the Reporting Questionnaire for Children ${ }^{(21)}$. The results of these authors are in partial agreement with our results, but we found a lower frequency of mental disorders than their observations. Possible explanations for these differences could be that our children were examined at a younger age, when mental disorder prevalence is lower, and that different test instruments were used.

With respect to the literature on the previously referred subject, we are able to state that preschoolaged children are at a good age to be screened for mental and cognitive disorders, which can alter learning to read and write. The majority of children who exhibited cognitive and emotional disorders in our sample had mild alterations, and cannot be assigned a diagnosis of a mental disorder, such as mental retardation, Attention deficit-hyperactivity disorder (ADHD), autism or language disorders. However, our data suggest that a high percentage of preschool children are at high risk of developing a learning disability later. Thus, we recommend universal screening for mental and cognitive disorders at preschool age, prior to the time when children suffer academic failure in elementary school, so as to prevent and treat children before they enter primary school and to ensure their academic development.

\section{References}

1. Poblano A, Fukumoto-Okamoto LE, Silva-Valencia MJ, Martínez-Wbaldo MC. Graphems development in preschool children (in Spanish). Pedagogia. 1996;11(6):36-41.

2. Sprafkin J, Volpe RJ, Gadow KD, Nolan EE, Kelly K. A DSMIV-referenced screening instrument for preschool children: the early childhood inventory-4. J Am Acad Child Adolesc Psychiatry. 2002;41(5):604-12.

3. Poblano A, Romero E. ECI-4 screening of attention deficit-hyperactivity disorder and co-morbidity in Mexican preschool children. Preliminary results. Arq Neuropsiquiatr. 2006;64(4):932-6.

4. Rosselli M, Matute E, Ardila A. Neuropsychological predictors of reading ability in Spanish (in Spanish). Rev Neurol. 2006(4);42:202-10.

5. Poblano A, Valadez-Tepec T, Arias ML, García-Pedroza F. Phonological and visuo-spatial working memory alterations in dyslexic children. Arch Med Res. 2000;31(5):493-6.

6. Poblano A, Borja S, Elías Y, García-Pedroza F, Arias ML. Characteristics of specific reading disability in children from a neuropsychological clinic in Mexico City. Salud Publica Mex. 2002;44(4):323-7.

7. Fletcher TV, López-Klinger KC. A Mexican perspective on learning disabilities. J Learn Disab. 1995;28(Special issue):5304,544 .
8. World Medical Association Inc. Declaration of Helsinki. Ethical principles for medical research involving human subjects. J Indian Med Assoc. 2009;107(6):403-5.

9. Fuentes M. Statistical issues in health impact assessment at the state and local levels. Air Qual Atmos Health. 2009:2(1):47-55.

10. de la Peña F, Estrada A, Almeida L, Páez F. Prevalence of depressive disorders and their relationship with low academic performance in students of secondary school (in Spanish). Salud Mental (Mexico). 1999;22(4):9-13.

11. Braga MR, Avila LA. Detection of pervasive disorders in the child: a maternal perspective (in Portugues). Rev. Latino-Am. Enfermagem. 2004; 12(6):884-9.

12. Santa Maria-Menger MR, Martins Linhares MB. Risk factors for infant developmental problemas. Rev. Latino-Am. Enfermagem. 2007;15(Special issue ):837-42.

13. Sastre-Riba S. High-ability children and their differential cognitive functioning (in Spanish). Rev Neurol. 2008;46(Suppl 1): s11-s16.

14. Lundberg I. Early precursors and enabling skills of reading acquisition. Scand J Psychol. 2009; 50(6):611-6.

15. Maslow P, Frostig M, Lefever DW, Whittlesey JR. The Marianne Frostig development test of visual perception, 1963 standarization. Pecept Mot Skill. 1964;Oct 19(Special issue):463-99. 
16. Bögels SM, Zigterman D. Disfunctional cognition in children with social phobia, separation anxiety disorder, and generalized anxiety disorder. J Abnorm Child Psychol. 2000;28(2):205-11. 17. Nicolson RI, Fawcett AJ, Berry EL, Jenkins $H$, Dean $P$, Brooks DJ. Association of abnormal cerebellar activation with motor learning difficulties in dyslexic adults. Lancet. 1999; 353(9165):1662-7.

18. Poblano A, Ishiwara K, Arias ML, García-Pedroza F, Marín H, Trujillo $\mathrm{M}$. Motor control alteration in posturography in learning disabled children. Arch Med Res. 2002;33(5):485-8.
19. Crawford SG, Dewey D. Co-occurring disorders: a possible key to visual perceptual deficits in children with developmental coordination disorder? Hum Mov Sci. 2008;27(1):154-69.

20. Babzakova-Trajkov G, Hamm JP, Waldie KE. The effects of redundant stimuli on visuo-spatial processing in developmental dyslexia. Neuropsychologia. 2005;43(3):473-8.

21. Rico H, Magis C, Guerrero MG, Gómez M, Ruiz CT, Vargas O, Silva JS. Frequency of mental disorders in first year of primary school children (in Spanish). Salud Mental (Mexico). 1998; 21(4):12-8. 